\title{
Price Transmission Analysis: the Case of Milk Products in Russia
}

\author{
Sergei Kharin
}

Faculty of Economics, Voronezh State University of Forestry and Technologies named after G. F. Morozov, Voronezh, Russia

\begin{abstract}
This paper investigates vertical price transmission along the milk supply chain in the Russian market using a vector autoregression model. Monthly farm-gate and retail prices were used in the analysis. Using cointegration technique, we find no empirical evidence for cointegration between farm-gate and retail prices. We show that there is bidirectional Granger causality from farm to retail prices and vice versa. However, response of the farm-gate price to a change in retail price is greater and slightly longer than price response of the retail price to a change at the farm level. The results support the assumption that price changes are not transmitted efficiently from one level to another.
\end{abstract}

\section{Keywords}

Vertical price transmission, market power, cointegration, vector autoregression model, dairy prices, Russia.

Kharin, S. (2018) "Price Transmission Analysis: the Case of Milk Products in Russia", AGRIS on-line Papers in Economics and Informatics, Vol. 10, No. 1, pp. 15-23. ISSN 1804-1930. DOI 10.7160/aol.2018.100102.

\section{Introduction}

In Russia, dairy producers express concerns about the fact, that price changes are not transmitted efficiently from farmers to retailers. This state of play caused reallocation of incomes from rural sector to other sectors. There was a great deal of studies to analyze vertical price transmission that applied time series econometric procedures. However, much analysis on vertical price transmission in the food markets focuses only on selected countries rather than Russia. In this context, we are motivated to study vertical price transmission along the dairy supply chain in Russia to get good insight into the price interaction at the various levels of marketing chain (farm-retail). There is some gap in our knowledge concerning price transmission on Russian food markets that the paper sought to fill. Kharin (2015) used farmgate and retail prices for estimating the vertical price linkages along the whole milk supply chain in one of the Russian region. The findings provide evidence of unidirectional Granger causality from retail to farm prices and not vice versa. Pokrivcak and Rajcaniova (2013) examine price transmission mechanism between farm and retail levels in vertical chain of potatoes in Slovakia. They found an evidence of structural break and existence of asymmetry in price transmission along the potato supply chain. Dai Jiawu et el. (2017) estimated the VAR systems for pork retail price and price transmissions in different links of China. Empirical results indicated the asymmetry of price transmission in the Chinese pork market, and demand and supply shocks from three food scare incidents were found to impact retail price and price transmissions differentially. Byeong-il Ahn and Hyunok Lee (2015) investigate the asymmetry of price transmission in the marketing chain of shipping points and terminal markets for fresh fruits in the western United States. Their results indicate that the price adjustments and asymmetry patterns are closely related to product characteristics, especially the intensity of product perishability. In the study of Zhuo Ning and Changyou Sun (2014), the degree of vertical integration and the presence of asymmetric price transmission are investigated for saw timber and lumber products in the southern and western United States. Asymmetric price transmission is found along the timber supply chain. In the long term, prices are more responsive when the price margin is increased than decreased. The paper by Byeong-il Ahn and Hyunok Lee (2013) extends the estimation of price relationships in wood processing and empirical assessment of asymmetric price transmission by incorporating time lags in both explanatory and dependent variables. The empirical findings in this study suggest the potential for lower wholesale prices of fiberboard with more competition in wholesale marketing. Fousekis et el. (2016) 
investigate vertical price transmission in the US beef supply chain. The empirical results indicate the presence of asymmetry in magnitude for the pair of markets farm-wholesale and the presence of both asymmetry in speed and asymmetry in magnitude for the pair of markets wholesale-retail.

In general, it is clear, that, mostly, prices are imperfectly transmitted along the supply chain. That is, a shock to prices at one level (say, the farm level) is not instantaneously passed through to wholesale and retail prices, as assuming perfect competition and zero profits would predict. There are good reasons for less than full pass-through apart from the existence of market power (for example, menu costs to changing prices, fixed-price contracts).

The main aim of this paper is to investigate vertical price transmission on the diary market in Russia. The paper addresses following research questions. Firstly, the long-term relationship between the milk prices at farm-gate and retail level is analysed. Subsequently, the price transmission elasticity is estimated. The contribution of the paper is twofold. Firstly, it provides a review dealing with the issue of price transmission in Russian dairy market. Secondly, it gives empirical evidence of vertical price linkages in the Russian dairy sector by taking into account the structural breaks.

\section{Materials and methods}

The price transmission analysis has been carried out using monthly dairy prices from 2002 to 2014 at the farm-gate and retail levels in Russian Federation. The source of the data is the Federal State Statistics Service of Russia. We use the logarithmic transformation of monthly prices measured in Russian rubles per liter.

The influence of farm-gate (retail) price on retail (farm-gate) price is investigated using multiple linear regressions. Initially, we consider $P_{1 t}$ to be the (natural) logarithm of retail price and $P_{2 t}$ to be the (natural) logarithm of farm-gate price.

Then we specify the model (Ansah, 2012)

$P_{1 t}=\alpha+\beta P_{2 t}+{ }_{\gamma} G_{t}+\varepsilon_{t}$

where $t$ - index of time, $\alpha$ - constant term (the log of a proportionality coefficient), $\beta$ - the elasticity (magnitude) that measures the percentage change in price $P_{1}$ (retail) due to a one percentage change in price $P_{2}$ (farm-gate), $G_{t}$ - government policy variable.

If there is a stationarity in the data, then equation 1 can be estimated with ordinary least squares
(OLS) regression. Stationarity represents a process in which the mean and standard deviation does not change over time. But mostly price time series are non-stationary that generally leads to spurious regression. A spurious regression has significant relationship between variables but the results are in fact without any economic meaning. In the presence of non-stationary data, it is required to carry out some transformation such as differencing (or detrending) to make them stationary. Thus, equation 1 cannot be estimated correctly with OLS. However, pairs of non-stationary price series can have a long-term relationship between them. If a price series is differenced once (by subtracting Pt-1 from Pt) and the differenced series is stationary, the time series is then "integrated of order 1", denoted by I (1). Non-stationarity means presence of unit roots. A variable contains a unit root if it is non-stationary.

$P_{t}=\beta P_{t-1}+\varepsilon_{t}$

In the equation 2 if $\beta=1$ the model is characterised by unit root, stationarity requires that $-1<\beta<1$. In testing for the presence of unit roots, several methodological options are available. Widely used among them are the Augmented Dickey-Fuller (ADF) test (Dickey and Fuller, 1979) as well as the Phillips-Perron test (Phillips and Perron, 1988).

As a standard procedure to test the non-stationarity of price series the ADF test uses following regression:

$P_{t}=c+\beta t+\alpha P_{t-1}+\sum_{i=1}^{k} \psi_{i} \Delta P_{t-i}+\varepsilon_{t}$

where $P_{t}$ - natural logarithm of the price, $c$ - intercept, $t$ - linear time trend. This regression includes $k$ lagged first differences to account serial correlation.

Phillips-Perron test builds on ADF test. While the ADF test uses a parametric autoregression, a great advantage of PP test is that it is nonparametric, i.e. it does not require to select the level of serial correlation as in ADF. The main disadvantage of the PP test is that it works well only in large samples. And it also shares disadvantages of ADF tests: sensitivity to structural breaks, poor small sample power resulting.

The Phillips-Perron and ADF tests specify the null hypothesis that a time series is non-stationary, i.e. unit root is present. In small samples, the general observation is that the Augmented Dickey-Fuller and Phillips-Perron tests have low power.

Often structural breaks present in time series (for instance, change in government policy which is denoted with $G_{t}$ in equation 1). Structural breaks 
can result in wrong conclusion about the presence of unit root. Therefore, we should apply unit root test taking into account the presence of structural breaks.

Zivot-Andrews (1992) test is an Augmented Dickey-Fuller (ADF) based unknown structural break test which estimates the model assuming a possible break at each point and chooses the break date where the t-statistic from ADF test of unit root is at minimum. In our case, ZA test is more preferable as we do not know the exact date of structural break (in comparison with other unit root tests for structural breaks).

The test runs the following three regression models:

1. model A which allows for a one-time change in the intercept of the series;

2. model B which permits a one-time change in the slope of the trend function;

3. model $\mathrm{C}$ which combines a one-time structural break in the intercept and trend.

The models are given below:

$$
\begin{aligned}
& P_{t}=a+\varphi P_{t-1}+\sum \theta_{i} \Delta P_{t-i}+\beta_{t}+{ }_{\gamma} D_{t}+\mu_{t} \\
& \text { (Model A) } \\
& P_{t}=a+\varphi P_{t-1}+\sum \theta_{i} \Delta P_{t-i}+\beta_{t}+{ }_{\gamma} D T_{t}+\mu_{t} \\
& \text { (Model B) } \\
& P_{t}=a+\varphi P_{t-1}+\sum \theta_{i} \Delta P_{t-i}+\beta_{t}+{ }_{\gamma} D_{t}+d D T_{t}+\mu t \\
& \text { (Model C) }
\end{aligned}
$$

where $D_{t}$ is a dummy variable to capture an intercept shift occurring at each possible break date $\left(T_{B}\right)$, and $D T_{t}$ is a trend shift dummy variable. $D_{t}$ equals 1 if $t>T_{B}$, and 0 otherwise; and $D T_{t}$ equals $t-T_{B}$ if $t>T_{B}$, and 0 otherwise.

The null hypothesis in all the three models is that the series contains a unit root with a drift that excludes any structural break, while the alternative hypothesis implies that the series are a trendstationary with a one-time break occurring at an unknown point in time.

Co-integration means that prices move closely together in the long-run, while in the short-run they may drift apart. There might be a linear combination of same integrated price series that is stationary. Co-integration analysis is used to estimate long-run price relations between non-stationary and same integrated variables.

Given that some of price series will be nonstationary, we will apply conventional GrangerEngle approach to test for co-integration. Engle and Granger (1987) used a technique to test for co-integration which included the static following regression estimated with OLS:

$\tilde{P}_{1 t}=a+\beta \tilde{P}_{2 t}+\varepsilon_{t}$

If $\tilde{P}_{1 t}$ and $\widetilde{P}_{2 t}$ are I(1) price series, then the residuals $v_{t}$ from the regression would be $\mathrm{I}(0)$ if they are co-integrated. So, if the residuals are I(1) we accept the null hypothesis of non-cointegration, otherwise, if the residuals are stationary, $\mathrm{I}(0)$, we reject the null hypothesis and accept that $\tilde{P}_{1 t}$ and $\tilde{P}_{2 t}$ are co-integrated.

ADF test for unit roots is applied to residuals from the co-integrating regression. First, we should test whether the price series have the same order of integration using unit root tests. If both price series have the same order of integration, we will carry out test for co-integration between the prices.

However, the power of Engle-Granger test is decreased if there is a structural break in co-integrating relationship. To avoid this problem, Gregory and Hansen (1996) improved the EngleGranger regression in order to take into account structural breaks in the intercept or in the intercept and trend. These models are specified as follows:

Model C: Level shift

$P_{1 t}=\mu_{0}+\mu_{1} \varphi_{t}+\alpha P_{2 t}+\varepsilon_{t}$

Model C/T: Level shift with trend

$P_{1 t}=\mu_{0}+\mu_{1} \varphi_{t}+\beta_{t}+\alpha P_{2 t}+\varepsilon_{t}$

Model C/S: Regime shift

$P_{1 t}=\mu_{0}+\mu_{1} \varphi_{t}+\alpha_{1} P_{2 t}+\alpha_{2} \varphi_{t} P_{2 t}+\varepsilon_{t}$

where $\varphi_{t}-$ dummy variable equals 1 if $t>\mathrm{T}$, 0 otherwise; $\mathrm{T}=[n \tau]$ point at which a break occurs $(n-$ sample size, $\tau \in(0,1)$ ).

Gregory and Hansen (1996) suggested three statistics for aforementioned models: $\mathrm{ADF}^{*}, \mathrm{Z}_{\mathrm{a}}{ }^{*}, \mathrm{Z}_{\mathrm{t}}^{*}$. They are corresponding to the traditional ADF test and Phillips type test of unit root on the residuals.

First, for each possible breakpoint $\mathrm{T}$, estimate the models (8)-(10) by OLS, obtaining the residual series $\left(\varepsilon_{t}\right)$ from which we can get the values of ADF, $Z_{\mathrm{t}}, \mathrm{Z}_{\mathrm{a}}$ test statistics. $\mathrm{Z}_{\mathrm{t}}$ and $\mathrm{Z}_{\mathrm{a}}$ test statistics were suggested by Phillips (1987). According to Gregory and Hansen, we compute the test statistics for each possible break point in the interval $[0.15 n, 0.85 n]$. The statistic of the cointegration test with breaks $\left(\mathrm{ADF}^{*}, \mathrm{Z}_{\mathrm{a}}^{*}, \mathrm{Z}_{\mathrm{t}}^{*}\right)$ is the smallest value of the conventional ADF, $\mathrm{Zt}$ and $\mathrm{Za}$ test statistics across all values of every possible breakpoint.

Second, compare the value of $\mathrm{ADF}^{*}, \mathrm{Z}_{\mathrm{a}}{ }^{*}$, $\mathrm{Z}_{\mathrm{t}}^{*}$ test statistics and the critical value given 
by Gregory and Hansen (1996). The single break date in these models is endogenously determined. The null hypothesis of non-cointegration with structural breaks is tested against the alternative of cointegration by Gregory and Hansen approach. The null hypothesis is rejected if the statistics $\mathrm{ADF}^{*}, \mathrm{Z}_{\mathrm{a}}^{*}, \mathrm{Z}_{\mathrm{t}}^{*}$ are less than critical values.

After testing for co-integration we will apply the Granger Causality test (1969) to evaluate the possible direction of the price transmission. The basic principle of Granger causality is that two variables $P_{1}$ and $P_{2}$ can have influence on one another. The starting point of the method is that $P_{1}$ variable Granger causes $P_{2}$ variable but $P_{2}$ does not Granger cause $P_{1}$.

$$
P_{2 t}=\sum_{i=1}^{n} \alpha_{i} P_{2 t-i}+\sum_{j=1}^{q} \beta_{j} P_{1 t-j}+v_{t}
$$

where $v_{t}$ - the white noise, $n, q-$ the lag order of $P_{2}$ and $P_{1}$ variables respectively.

In our study, $P_{2}$ and $P_{1}$ is the retail and farm-gate prices, the $\alpha$ 's and $\beta$ 's are parameters. We test for the significance of the $\beta$ 's and if they are jointly significant, then we conclude that $P_{1}$ Granger causes $P_{2}$. We assume that there is a linear relationship between the farm-gate and retail prices. The Granger causality test needs that the variables should be stationary.

In order to determine the optimum lags in the models, the Akaike (1973) information criterion [AIC] and the Schwarz-Bayesian (1978) information criterion [BIC] are used. Serena and Perron (2001) proposed the modified versions of AIC (mAIC) and BIC (mBIC) as a model selection criterion which are based on quasi-likelihood function.

If the price series are co-integrated we estimate a Vector Error Correction model (VECM), otherwise, we build Vector Autoregression model (VAR) for farm-gate and retail prices in order to investigate price dynamic relationships.

The Vector Autoregression (VAR) models has been widely used for modelling and forecasting since the paper of Sims (1980). A VAR model is a system of multivariate models in which each variable is explained by its own past values and the past values of all other variables in the system. A VAR model is vector of price series. It comprises one equation per price variable considered in the system.

The VECM is a special case of VAR models that takes into account co-integration relationships between price series. If our tests reveal non-cointegration, we can specify and estimate VAR model. The VAR model includes two equations and can be written as equations 12,13 . The right hand side of each equation includes a constant $\left(\alpha_{0}, \beta_{0}\right)$, lags of all the variables in the system and an error term. All variables must be of the same order of integration.

$$
\begin{aligned}
& P_{1 t}=\alpha_{0}+\alpha_{1} P_{1 t-1}+\ldots+\alpha_{k} P_{1 t-k}+\gamma_{1} P_{2 t-1} \\
& +\ldots+\gamma_{k} P_{2 t-k}+\varepsilon_{t} \\
& P_{2 t}=\beta_{0}+\beta_{1} P_{2 t-1}+\ldots+\beta_{k} P_{2 t-k}+c_{1} P_{1 t-1} \\
& +\ldots+c_{k} P_{1 t-k}+\varepsilon_{t}
\end{aligned}
$$

where $P_{1 t}$ and $P_{2 t}$ - farm-gate and retail prices, $P_{1 t-k}$ and $P_{2 t-k}$ - lagged farm-gate and retail prices.

If the price series are stationary we model them by directly fitting a VAR to the data. If the series are non-stationary we take differences to make them stationary and then we fit a VAR model. In both cases, the models are estimated equation by equation using the method of least squares. For each equation, the parameters are estimated by minimising the sum of squared $\varepsilon$ t values.

The VAR model includes the Granger causality results (testing whether one price variable is useful in forecasting another). As a drawback, individual coefficients in the estimated VAR models are often difficult to interpret, users of this technique often estimate the impulse response function (the response of one price variable to a sudden and temporary change in another price variable). The VAR model generates the impulse response function that indicates us about how fast a price shock at one price transmits towards another price. It describes the response of one variable to an impulse of another variable.

\section{Results and discussion}

Stationarity of the price series was checked with the conventional ADF test and Phillips-Perron test. The number of optimal lags was determined using mBIC. Our preliminary visual examination of price series graphs gives us the insight that model for unit-root test should contain constant and a time trend. The null hypothesis $\mathrm{H} 0$ is rejected if the critical value is greater than test statistic ( $p$-value is less than level of significance). The results are summarized in table 1 .

The output presented in table 1 shows that null hypothesis of stationary price series in levels was rejected for all variables except for farm prices for whole milk. The lag length was 6 . However, at higher lag length the null hypothesis of stationarity for farm price series was rejected as well. Tests based on first differences show that all 


\begin{tabular}{|c|c|c|c|c|c|c|c|c|c|}
\hline \multirow{2}{*}{$\begin{array}{l}\text { Price variable } \\
\text { (log price) }\end{array}$} & \multirow{2}{*}{ Model } & \multicolumn{4}{|c|}{ ADF test } & \multicolumn{4}{|c|}{ Phillips-Perron test } \\
\hline & & Lag & Levels & Lag & First difference & Lag & Levels & Lag & First difference \\
\hline \multirow{2}{*}{$\begin{array}{l}\text { Farm-gate } \\
\text { price }\end{array}$} & Trend \& intercept & 6 & $\begin{array}{c}-2.3758 \\
(0.3923)\end{array}$ & 1 & $\begin{array}{l}-6.049 * * * \\
(8.79 \mathrm{e}-07)\end{array}$ & 6 & $-3.807 * *$ & 1 & $-5.2149 * * *$ \\
\hline & Intercept only & 6 & $\begin{array}{l}-0.3549 \\
(0.9143)\end{array}$ & 1 & $\begin{array}{l}-6.074 * * * \\
(7.94 \mathrm{e}-08)\end{array}$ & 6 & -0.74 & 1 & $-4.894 * * *$ \\
\hline \multirow{2}{*}{ Retail price } & Trend \& intercept & 7 & $\begin{array}{c}-1.227 \\
(0.9041)\end{array}$ & 1 & $\begin{array}{l}-6.899 * * * \\
(4.84 \mathrm{e}-09)\end{array}$ & 7 & -1.8498 & 1 & $-7.4852 * * *$ \\
\hline & Intercept only & 1 & $\begin{array}{c}-0.6161 \\
(0.8648)\end{array}$ & 1 & $\begin{array}{l}-6.91 * * * \\
(5.865 \mathrm{e}-10)\end{array}$ & 7 & -0.5805 & 1 & $-7.1594 * * *$ \\
\hline
\end{tabular}

Notes: ** - null hypothesis of non-stationarity rejected at $5 \%$ of significance; *** - null hypothesis of non-stationarity rejected at $1 \%$ of significance; the value in parentheses indicates p-value.

Source: own calculations

Table 1: Unit root test results in levels and first differences.

the test statistics are significant at $1 \%$ critical level. Hence, we can conclude that all price variables are integrated of the order one, I (1). Our findings allow us to assume that there is co-integration between farm and retail dairy prices which is required to be investigated.

As we were saying above, the presence of structural breaks can lead to wrong conclusions concerning time series stationarity. To solve this problem, we investigated the stationarity using Zivot-Andrews (1992) approach. The results are presented in table 2 .

From the table 2, we can see that we cannot reject null hypothesis of non-stationarity at $1 \%$ and $5 \%$ of significance. Therefore, structural breaks are insignificant and we will not take them into account. Hence, we can sum up that our price series are I (1) and we first will run the conventional test of Engle and Granger and then Gregory-Hansen tests.

Within this test for co-integration the static equation is first estimated with OLS and then the stationarity of the residuals of the relationship (between farm and retail prices for whole milk) is tested with the ADF test using the critical values proposed by MacKinnon (1991). If the residuals are revealed to be stationary, the price pair is identified to be cointegrated. We set the maximum lag in accordance with Schwert (1989) rule and used the information criterions to select appropriate lag lengths. ADF test statistics for Engle-Granger test are shown in table 3.

As we can see, we cannot reject the null hypothesis of non-cointegration in the milk farm-retail chain.

According to the findings in the table 4, we also can not reject the null hypothesis of GregoryHansen cointegration test since two or more test statistics exceed critical values at $1 \%$ and $5 \%$ level of significance. When we select a significance level, one should pay attention to the sample size. With a small sample size, it is more likely to get a random result. Therefore, we can apply a higher probability of Type I error. If we increase a sample size, random deviations compensate for each other, and it is less likely to obtain a significant difference in homogeneous samples. Therefore, it is necessary to apply a lower significance level. If the sample size is small (less than 100 variables), it is possible to reject the null hypothesis at a significance level of $5 \%$ or even $10 \%$. Our price series are more than 100 variables. Bross (1971) points out that the continuing usage of the $5 \%$ level is indicative of another important practical point: it is a feasible level at which to do research work.

Hence, we found that both price pairs are not co-integrated and we will specify and estimate VAR model in first differences. According to our findings, we can specify VAR model in first differences and estimate dynamic effects in farmretail price relationships via Impulse Response Function graphs (table 5 and figure 1).

Then we should implement Granger causality F-tests of zero restrictions within the framework of VAR. In order to estimate the possible direction of price transmission, we carried out Granger causality test. The appropriate lag length was selected in accordance with BIC. In order to avoid autocorrelation problem we computed HAC (heteroskedasticity and autocorrelationconsistent) standard errors within the model. As shown in table 6, the direction of price transmission goes from retailers to farmers and vice versa. 


\begin{tabular}{|c|c|c|c|c|}
\hline \multicolumn{2}{|c|}{ Price variable (logarithm in levels) } & \multicolumn{3}{|c|}{ Zivot-Andrews test } \\
\hline \multirow{2}{*}{ Farm-gate prices } & Test statistic & -3.659 & -3.3902 & -3.7944 \\
\hline & Break date & July 2007 & November 2007 & September 2007 \\
\hline Retail prices & Test statistic & -4.0569 & -4.3724 & -4.9386 \\
\hline
\end{tabular}

Critical values for: 1) break in intercept only - 1\% (-5.34), 5\% (-4.8); 2) break in trend only - 1\% (-4.93), 5\% (-4.42); 3) both in intercept \& trend - $1 \%(-5.57), 5 \%(-5.08)$

Source: own calculations

Table 2: Unit root test with one structural break.

\begin{tabular}{lcc}
\hline \multirow{2}{*}{ Price pair (in logarithms) } & \multicolumn{2}{c}{ Test value } \\
\cline { 2 - 3 } & Intercept only & Trend \& intercept \\
\hline \multirow{2}{*}{ Dairy prices (farm-retail) } & -1.7854 & -2.1404 \\
\hline
\end{tabular}

Notes: the value in parentheses indicates p-value (level of significance)

Source: own calculations

Table 3: Cointegration test (Engle-Granger test).

\begin{tabular}{|c|c|c|c|c|c|c|c|}
\hline Model & & \multicolumn{2}{|l|}{ ADF* } & \multicolumn{2}{|l|}{$\mathrm{Zt} *$} & \multicolumn{2}{|l|}{$\mathrm{Za}^{*}$} \\
\hline $\mathrm{C}$ & & $\begin{array}{c}0.78 \\
\text { (November, 2011) }\end{array}$ & -4.175 & $\begin{array}{c}0.48 \\
\text { (January, 2008) }\end{array}$ & -4.507 & $\begin{array}{c}0.48 \\
\text { (January, 2008) }\end{array}$ & -36.437 \\
\hline \multirow{2}{*}{ Critical value } & $1 \%$ & \multicolumn{2}{|l|}{-5.13} & \multicolumn{2}{|l|}{-5.13} & \multicolumn{2}{|l|}{-50.07} \\
\hline & $5 \%$ & \multicolumn{2}{|l|}{-4.61} & \multicolumn{2}{|l|}{-4.61} & \multicolumn{2}{|l|}{-40.48} \\
\hline \multirow{2}{*}{ Critical value } & $1 \%$ & \multicolumn{2}{|l|}{-5.45} & \multicolumn{2}{|l|}{-5.45} & \multicolumn{2}{|l|}{-57.28} \\
\hline & $5 \%$ & \multicolumn{2}{|l|}{-4.99} & \multicolumn{2}{|l|}{-4.99} & \multicolumn{2}{|l|}{-47.96} \\
\hline $\mathrm{C} / \mathrm{S}$ & & $\begin{array}{c}0.52 \\
\text { (July, 2008) }\end{array}$ & $-8.577 * * *$ & 0.5 (April, 2008) & -4.943 & 0.5 (April, 2008) & -45.43 \\
\hline
\end{tabular}

Notes: critical values have been taken from Gregory-Hansen (1996)

Source: own calculations

Table 4: Cointegration test with structural break for farm-retail chain (Gregory-Hansen test).

\begin{tabular}{lcc}
\hline \multicolumn{1}{c}{ Dependent variable } & $\Delta \operatorname{lnFarm} \_$milkt & $\Delta$ lnRetail_milkt \\
Regressors & -0.003463 & $0.006173^{* * *}$ \\
\hline Intercept & $(0.004098)$ & $(0.001785)$ \\
& {$[-0.8451]$} & {$[3.457]$} \\
\hline$\Delta \ln$ _Retail_milkt-1 & $0.646567 * * *$ & $0.377215^{* * *}$ \\
& $(0.176087)$ & $(0.056886)$ \\
& {$[3.672]$} & {$[6.631]$} \\
\hline$\Delta$ ln_Farm_milkt-1 & $0.588054 * * *$ & $0.069011^{* *}$ \\
& $(0.072582)$ & $(0.029513)$ \\
& {$[8.102]$} & {$[2.338]$} \\
\hline R ${ }^{2}$ & 0.5896 & 0.2356 \\
Adjusted R ${ }^{2}$ & 0.584 & 0.2253 \\
S.E. of regression & 0.037924 & 0.021693 \\
Sum sq.resid & 0.212859 & 0.069645 \\
Mean dependent & 0.008834 & 0.010858 \\
S.D. dependent & 0.0588 & 0.024646 \\
F-statistic & 147.22 & 46.7 \\
\hline
\end{tabular}

Notes:

1. Estimates are given, taking into account HAC standard errors;

2 . values in ()$,[]$ are standard errors and t-statistics respectively;

3. *** - $1 \%$ significance level; $* *-5 \%$ significance level;

4. $\Delta$ lnFarm milk -farm log-price for whole milk (in first difference); $\Delta \operatorname{lnRetail\_ milk~-~retail~log-price~for~whole~milk~}$ (in first difference);

5. Lag order has been selected in accordance with information criteria (SBIC);

6. Since time trend is statistically insignificant and also have not significant effect on the whole regression model, this variable was eliminated from the model.

Source: own calculations

Table 5: Vector Autoregression Estimates. 


\begin{tabular}{lc}
\hline Null Hypothesis & $\begin{array}{c}\text { F-statistics } \\
\text { (p-value) }\end{array}$ \\
\hline DlnFarm_milk does not cause $\Delta \ln$ Retail_milk (lag 1) & $5.4677^{* *}$ \\
& $(0.0207)$ \\
DlnRetail_milk does not cause $\Delta$ lnFarm_milk (lag 1) & $13.483 * * *$ \\
& $(0.0003)$ \\
\hline
\end{tabular}

Notes: $\Delta \operatorname{lnFarm} \_$milk -farm log-price for whole milk (in first difference);

$\Delta \operatorname{lnRetail\_ milk~-~retail~log-price~for~whole~milk~(in~first~difference);~} * * * 1 \%$

significance level; ** 5\% significance level;

Source: own calculations

\section{Table 6: Granger causality F-test.}
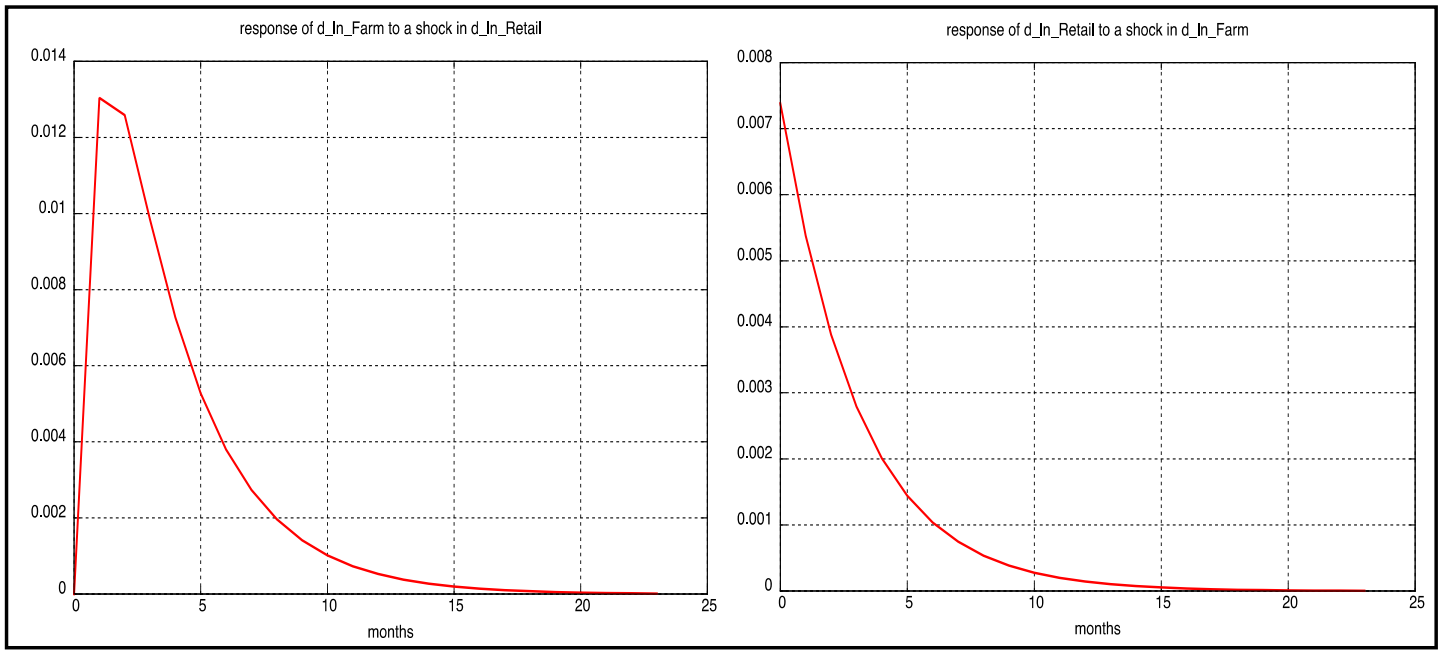

Source: own calculation

Figure 1: The impulse response of variables to each other.

Hence, the results of the VAR indicate that there is a positive and significant relationship between the farm-gate price for whole milk and the retail price. Further from the analysis of the impulse response function (figure 1) we revealed that a one-standard deviation shock to retail price causes an increase in farm price, followed by a gradual decrease until the effect dies out after 16 months. Farm price change reaches a maximum on the second month after the initial retail price change shock to the economy. A one-standard shock to farm price causes retail price to peak immediately, then it begins to decrease until the effect dies out after 14-15 months. The responses are all positive at each period of responsive period.

\section{Conclusion}

In this study we have investigated relationship between the farm-gate and retail prices for milk in Russia. Structural break tests revealed breaks but they were insignificant and have not been taken into account. Vertical price transmission was evaluated in the co-integration framework, using classical Engle-Granger and Gregory-Hansen approaches. The results have shown that a long-run co-integration relationship does not exist between farm and retail prices, that is, they do not move together. That is quite surprising that this finding is not in line with most studies on price transmission on the East European milk markets which found price series co-integration (Kharin et el., 2017; Lajdova and Bielik, 2015; Falkowski, 2010).

We have found evidence that change in one price has a significant effect on another one, that is, Granger test established bidirectional Granger causality from farm to retail prices and vice versa. However, response of the farm-gate price to a change in retail price is greater and slightly longer than price response of the retail price to a change at the farm level. One of the factor, underlying the fact that retailers have more market power than farmers. However, the argument about asymmetric price transmission goes further. The assertion is that, due to imperfect price transmission (especially caused by market power), a price reduction at the farm level is only slowly, and possibly not fully, transmitted through the supply chain. The implication is that the profit margins of the oligopolistic actors (those with the market power) will be higher than normal.

The absence of market integration in our study and complete pass-through of price changes 
from farmers to retailers has important implications for economic welfare (Rapsomanikis et el., 2003). Imperfect price transmission arising either due to trade and other policies, or due to transaction costs ( poor transport and communication infrastructure), results in a reduction in the price information available to economic agents and consequently may lead to decisions that contribute to inefficient outcomes.

Our study will help the Russian authorities that need to have a transparent picture in the price transmission on the milk market, and support the rural sector in the aspect of distribution and balancing of subsidies in the dairy chain. This study can be extended with including wholesale level in the analysis as well as using a wider range of advanced unit root and co-integration tests under multiple structural breaks.

\section{Acknowledgements}

The study was carried out within the state assignment of the Ministry of Education and Science of the Russian Federation (№ 26.12725.2018/12.2)

Corresponding authors:

Sergei Kharin, Cand. Sc. (Econ.), Researcher

Faculty of Economics, Voronezh State University of Forestry and Technologies named after G. F. Morozov 394087, Timiryazeva street, 8, Voronezh, Russia

E-mail:kharins03@gmail.com

\section{References}

[1] Akaike, H. (1973) "Information theory and an extension of the maximum likelihood principle", in B.N. Petrov and F. Csaki (eds), Proceedings of the $2^{\text {nd }}$ International Symposium on Information Theory. Budapest: Akademiai Kiado, pp. 267-281.

[2] Ansah, I. G. K. (2012) "Analyzing the relationship between world market prices and local prices of food in African markets: the case of wheat in Ethiopia", MSc Thesis, Wageningen University and Research Center, Wageningen.

[3] Banerjee, A., Dolado, J. Galbraith, J.W . and Hendry, D. F. (1993) "Co-Integration, Error-Correction, and the Econometric Analysis of Non-Stationary Data", Oxford, Oxford University Press. DOI 10.1093/0198288107.001.0001.

[4] Bross, I. D. J. (1971) "Critical levels, statistical language and scientific inference", In: Godambe $V P$, Sprott DA, editors. Foundations of statistical inference. Toronto: Holt, Rinehart \& Winston of Canada, Ltd.

[5] Byeong-il Ahn and Lee H. (2015) "Vertical Price Transmission of Perishable Products: The Case of Fresh Fruits in the Western United States", Journal of Agricultural and Resource Economics, Vol. 40, No.3, pp. 405-424. ISSN 1068-5502.

[6] Byeong-il, A. and Lee, H. (2013) "Asymmetric transmission between factory and wholesale prices in fiber board market in Korea", Journal of Forest Economics, Vol. 19, No.1, pp. 1-14. ISSN 1104-6899. DOI 10.1016/j.jfe.2012.06.008.

[7] Dai J., Li X. and Wang X. (2017) "Food scares and asymmetric price transmission: the case of the pork market in China", Studies in Agricultural Economics, Vol. 119, No. 2, pp. 98-106. ISSN 1418-2106. DOI 10.7896/j.1620.

[8] Dickey, D. A., Fuller, W. A. (1979) "Distribution of the estimators for autoregressive time series with a Unit Root", Journal of the American Statistical Association, Vol. 74, pp. 427-431.

[9] Elliott, G., Rothenberg, T. J. and Stock, J. H. (1996) "Efficient Tests for an Autoregressive Unit Root", Econometrica, Vol. 64, No. 4, pp. 813-836. ISSN 0012-9682. DOI 10.2307/2171846.

[10] Engle, R. F. and Granger, C. W. J. (1987) "Co-Integration and Error Correction: Representation, Estimation, and Testing", Econometrica, Vol. 55, No. 2, pp. 251-276. ISSN 0012-9682. DOI $10.2307 / 1913236$.

[11] Falkowski, J. (2010) "Price transmission and market power in a transition context: evidence from the Polish fluid milk sector", Post-Communist Economies, Vol. 22, pp. 513-529. DOI 10.1080/14631377.2010.518477. 
[12] Fousekis, P., Katrakilidis, C. and Trachanas, E. (2016) "Vertical price transmission in the US beef sector: Evidence from the nonlinear ARDL model", Economic Modelling, Vol. 52, Part B, pp.499-506. ISSN 0264-9993. DOI 10.1016/j.econmod.2015.09.030.

[13] Granger, C. W. J. (1969) "Investigating Causal Relations by Econometric Models and Cross-spectral Methods”, Econometrica, Vol. 37, No. 3, pp. 424-438. ISSN 0012-9682. DOI 10.2307/1912791.

[14] Granger, C. W. J. (1980) “Testing for causality: A personal viewpoint”, Journal of Economic Dynamics and Control, Vol. 2, pp. 329-352. ISSN 0165-1889.

[15] Granger, C. W. J. and Lee, T. H. (1989) "Investigation of production, sales and inventory relationships using multicointegration and non-symmetric error correction models", Journal of Applied Econometrics, Vol. 4, pp. 145-159. ISSN 1099-1255.

[16] Gregory, A. and Hansen, B. (1996) "Residual-based tests for cointegration in models with regime shifts”, Journal of Econometrics, Vol. 70, pp. 99-126. DOI 10.1016/0304-4076(69)41685-7.

[17] Kharin, S. (2015) "Vertical price transmission along the dairy supply chain in Russia", Studies in Agricultural Economics, Vol. 117, No. 2, pp. 80-85. ISSN 1418-2106. DOI 10.7896/j.1517.

[18] Kharin, S., Lajdova, Z. and Bielik, P. (2017) "Price transmission on the Slovak dairy market", Studies in Agricultural Economics, Vol. 119, No. 3, pp. 148-155. ISSN 1418-2106. DOI 10.7896/j.1711.

[19] Lajdová, Z. and Bielik, P. (2015) "The evidence of asymmetric price adjustments", Agricultural Economics-Zemedelská Ekonomika, Vol. 61, No. 3, pp. 105-115. DOI 10.17221/220/2014-AGRICECON.

[20] MacKinnon, J. (1991) “Critical Values for Cointegration Tests”, in R. Engle and C. Granger (eds), Long-Run Economic Relationships, Oxford, Oxford University Press, pp. 267-287.

[21] Ning, Z. and Sun, Ch. (2014) "Vertical price transmission in timber and lumber markets", Journal of Forest Economics, Vol. 20, No. 1, pp. 17-32. ISSN 1104-6899. DOI 10.1016/j.jfe.2013.07.002.

[22] Phillips, P. C. B. (1987) “Time series regression with a unit root”, Econometrica, Vol. 55, No. 2, pp. 277-301. ISSN 0012-9682.

[23] Phillips, P. C. B. and Perron, P. (1988) "Testing for a Unit Root in Time Series Regression", Biometrica, Vol. 75, No. 2, pp. 335-346. DOI 10.1093/biomet/75.2.335.

[24] Rajcaniova, M. and Pokrivcak, J. (2013) "Asymmetry in price transmission mechanism: the case of Slovak potato market", Review of agricultural and applied economics (RAAE), Vol.16, No.2, pp. 16-23. ISSN 1336-9261.

[25] Rapsomanikis, G., Hallam, D. and Conforti, P. (2003) "Market integration and price transmission in selected food and cash crop markets of developing countries: review and applications", FAO, Jan. 2003. [Online]. Available: http://www.fao.org/docrep/006/y5117e/y5117e06.htm [Accessed: 16 Feb. 2018].

[26] Schwarz, G. (1978) "Estimating the dimension of a model", The Annals of Statistics, Vol. 6, No. 2, pp. 461-464. ISSN 0090-5364. DOI 10.1214/aos/1176344136.

[27] Schwert, G. W. (1989) “Tests for Unit Roots: A Monte Carlo Investigation”, Journal of Business and Economic Statistics, Vol. 7, pp. 147-160. ISSN 0735-0015.

[28] Serena, N. and Perron, P. (2001) "Lag Length Selection and the Construction of Unit Root Tests with Good Size and Power", Econometrica, Vol. 69, No. 6, pp. 1519-1554. ISSN 0012-9682.

[29] Sims, C. (1980) "Macroeconomics and Reality", Econometrica, Vol. 48, No.1, pp. 1-48. ISSN 0012-9682.

[30] Zivot, E. and Andrews, D. (1992) "Further evidence of the great crash, the oil-price shock and the unit-root hypothesis", Journal of Business and Economic Statistics, Vol. 10, No. 3, pp. 251-270. ISSN 0735-0015. 